\title{
Damage assessment to subtropical forests following the 2008 Chinese ice storm
}

\author{
Benzhi Zhou ${ }^{(1-2)}$, \\ Xiaoming Wang ${ }^{(1-2)}$, \\ Yonghui Cao ${ }^{(1-2)}$, \\ Xiaogai Ge ${ }^{(1-2)}$, \\ Lianhong Gu ${ }^{(3)}$, \\ Jinliu Meng ${ }^{(1-2)}$
}

\begin{abstract}
Ice storm is a major form of extreme climatic event and may occur more frequently in the future under a changing climate. The 2008 Chinese ice storm provided a natural laboratory to study ecosystem responses and feedbacks to climate variability and extreme events. Four typical subtropical forests (Chinese fir plantation, pine plantation, moso bamboo plantation, and secondary mixed broadleaved forest) were selected to assess the damage caused by the ice storm. The ice damage rate of typical subtropical forests varied between $25 \%$ and $81 \%$. The secondary broadleaved forest had most extensive damage while the Chinese fir plantation experienced the most severe damage. Exotic pine species (Pinus elliottii Engelm. and Pinus taeda Linn.) were more severely damaged than the native species, Pinus massoniana Lamb. Ice damage was also affected by tree/culm size, age, stand density, site altitude, and management practices. Large-sized trees/culms were more vulnerable to stem breakage, decapitation, and uprooting, while small-sized trees/culms were more vulnerable to bending and leaning. Younger trees/culms had the highest damage rate, and were more susceptible to bending damage. Ice damage rate increased linearly with the stand density, and higher altitude led to a significant increase of stem breakage. Oleoresin tapping aggravated the damage to pine trees. Resistance of trees to ice damage is an emergent consequence of tree attributes, species origin, site conditions, and human disturbance. Forest silviculture and management practices can play significant roles in controlling forest susceptibility to extreme events. Inappropriate utilization of non-timber forest products can reduce trees' resistance to extreme events. For sustainable forest development, balance needs to be achieved between the high productivity of introduced exotic tree species and the resistance of native species to extreme climatic events.
\end{abstract}

Keywords: Ice Damage, Secondary Mixed Broadleaved Forest, Chinese Fir, Moso Bamboo, Pine, Forest Management objects. Ice storms can play a major role in defining geographical distributions of tree species and determining forest ecosystem structures (Millward \& Kraft 2004). Ice storm damage to forests can be diverse, ranging from broken branches in a single tree to complete disruption of the forest canopy. When forest canopy structure is damaged, within-canopy forest environments (e.g., light, temperature, soil nutrients, and water) can change suddenly with
(1) Research Institute of Subtropical Forestry, Chinese Academy of Forestry, Hangzhou, Zhejiang (China); (2) Qianjiangyuan Forest Ecosystem Research Station, State Forestry Administration, Hangzhou, Zhejiang (China); (3) Environmental Sciences Division, Oak Ridge National Laboratory, Oak Ridge, Tennessee (USA)

@ Benzhi Zhou (boozex@gmail.com)

Received: Feb 25, 2015 - Accepted: Dec 08, 2016

Citation: Zhou B, Wang X, Cao Y, Ge X, Gu L, Meng J (2017). Damage assessment to subtropical forests following the 2008 Chinese ice storm. iForest 10: 406-415. - doi: 10.3832/ifor1619-009 [online 2017-03-24]

Communicated by: Paola Mairota profound consequences on understory

An ice and snow storm occurred in early 2008 in China with a record-setting duration and severity. It affected 19 provinces, autonomous regions or municipalities with a population of over 100 million (Stone 2008 - Fig. 1). According to the Ministry of Civil Affairs, the storm claimed 129 lives. The total direct, short-term costs were estimated at US\$22.3 billion (Stone 2008).

The 2008 ice storm not only caused extensive social disruption and economic losses, but also brought a massive ecological disturbance to ecosystems. Large areas of forest were impacted, mostly in the provinces or autonomous regions in subtropical zone of China (Fig. 1). About 21 million hectares of natural and plantation forests were damaged by the storm, accounting for one-tenth of China's total forested area, according to China's State Forestry Administration (Zhou et al. 2011a). A total of 340 million $\mathrm{m}^{3}$ of standing volume was destroyed. Over 800 natural reserves were affected, and about 30,000 wild animals under special protection died or were injured (Zhou et al. 2013). communities (Zhou et al. 2011a). 


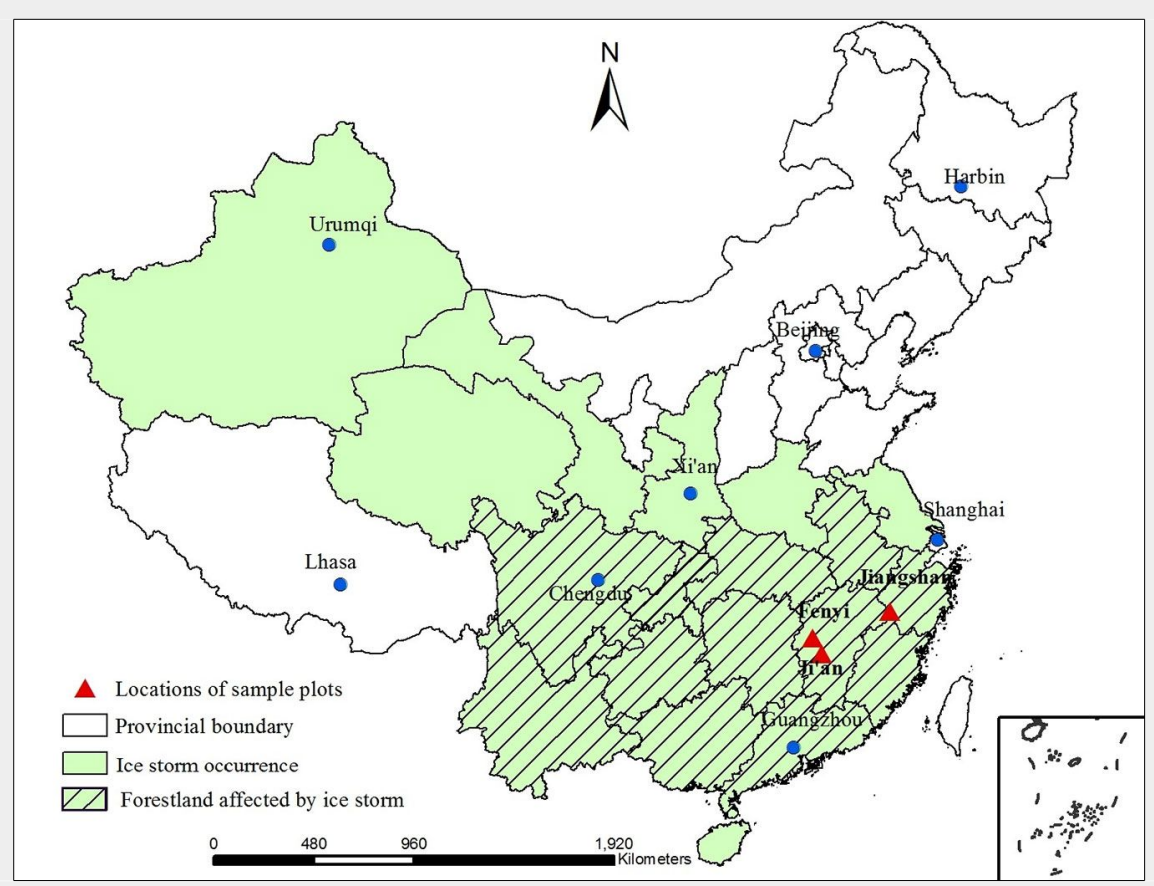

Fig. 1 - The occurrence areas of the 2008 Chinese ice storm and the study sites.

Subtropical area covers a quarter of the territory of China. The typical forest types in this region include Chinese fir (Cunninghamia lanceolata [Lamb.] Hook) plantations, pine plantations, moso bamboo (Phyllostachys heterocycla var. pubescens [Mazel] Ohwi) plantations, and secondary mixed broadleaved forests. Chinese fir, pine, and moso bamboo are the most important species in subtropical forest plantations in China. They provide the major raw materials for the timber processing industry in South China. Chinese fir is the dominant tree species in this region, with a total area of approximately $4 \times 10^{6}$ hectares, accounting for about $25 \%$ of plantations (Huang et al. 2005). Pine species in South China are mainly native masson pine (Pinus massoniana Lamb.) and exotic species, $\mathrm{Pi}$ nus elliottii Engelm. and Pinus taeda Linn. The plantation area of these three species occupies more than one third of timber plantations in South China. Moso bamboo is a distinctive "tree" species. It appears as a woody tree but belongs taxonomically to the grass family (Gramineae). The total area of moso bamboo plantations (4.2 million hectares) is lower than that of Chinese fir or pine plantations, but its importance is equivalent to pine and Chinese fir because of its rapid growth, versatile use, and short harvest cycle (Zhou et al. 2011b, Wang et al. 2013). These three forest types comprise the major material supply for timber production and play a pivotal role in rural economy in South China. The typical natural stands in this area are secondary mixed broadleaved forests, with dominant species coming from the families of Fagaceae, Lauraceae and Theaceae. Unlike plantations, which are mainly oriented to timber production, the natural forests are aimed for erosion control, water conservation and biodiversity protection.

Ice storms occasionally occur in some specific areas in Southern China, but extreme ice storm seldom manifests there (Zhou et al. 2011a), which leads to a general unawareness and unpreparedness for large ice storms. Partly because of this, ice storms and their associated risks are rarely considered in ecosystem management (Zhou et al. 2011b). Ice damage to trees is likely to depend on tree size, crown form, wood mechanical properties, stand structure, and many other factors in addition to ice storm intensity (Nadrowski et al. 2014). Since ice storms do not occur frequently in subtropical regions, research does not usually address ice damage to subtropical forests, where biodiversity is higher and the ecosystem structure is more complex than temperate forests (Bragg et al. 2003, Nadrowski et al. 2014). Little is known about the responses of subtropical forest trees to extreme disturbance of ice storms, which may increase in the coming decades in response to changes in climate, as current models suggested (Rustadlindsey \& Campbelljohn 2012, Klima \& Morgan 2015). It is essential to assess the impact of great ice storm on major forest types in subtropical areas, which will serve as valuable references in tree plantation and forest management in the future.

The 2008 Chinese ice storm provided a natural laboratory to study the ecosystem responses and feedbacks to climate variability and extreme events. Therefore, we selected four forest types as representatives of subtropical forest, and investigated their responses to the ice storm. Our primary objective for this study was to assess the impact of the ice storm on the four typical subtropical forest types. A second objective was to explore the main factors affecting the vulnerability or resistance of the forests to large-scale ice storm disturbance.

\section{Materials and methods}

\section{Study sites}

To assess the impact of the ice storm on subtropical forests in China, we carried out surveys immediately after the ice storm in Jiangxi and Zhejiang, the provinces where the typical subtropical forests were extensively damaged by this ice storm (Fig. 1). The study sites were located in hilly areas with an altitude between $200 \mathrm{~m}$ and $800 \mathrm{~m}$ above sea level. The soil belongs to yellowish brown lateritic soil type (Xi 1993), with a depth of around $1.0 \mathrm{~m}$. The slope varies from 20 to 30 degrees. The climate is subtropical monsoonal humid, with a mean annual temperature ranging from $15.8^{\circ} \mathrm{C}$ to $20{ }^{\circ} \mathrm{C}$. The annual precipitation ranges from about 1070 to $2532 \mathrm{~mm}$.

Four forest types were investigated in our study, i.e., Chinese fir (CF) plantation, pine (PN) plantation, moso bamboo (MB) plantation, and secondary mixed broadleaved (SB) forest. The survey of CF and MB plantations took place at the Subtropical Forest Experimental Center, Chinese Academy of Forestry, located in Fengyi County $\left(27^{\circ} 34^{\prime}\right.$ $\mathrm{N}, 114^{\circ} 33^{\prime} \mathrm{E}$ ), Jiangxi province. The sampled CF stand was an even-aged plantation that was established in the spring of 1981 using one-year-old seedlings in afforestation. The stand was thinned at an age between 10 and 15 years, to a target density varying between about 1500 and 5000 stem ha when the stand was surveyed. The sampled MB stand was an uneven-aged plantation that resulted from new culm generation each year from the rhizomes of the mother culms. The culms more than 7 years old in the stand were mostly cut in autumn and winter season each year, leaving younger culms in the stand. Survey of PN plantation and SB forest were implemented, respectively, at the Ji'an Forestry Center, Ji'an County $\left(27^{\circ} 03^{\prime} \mathrm{N}, 114^{\circ} 24^{\prime} \mathrm{E}\right)$, Jiangxi province, and Qianjiangyuan Forest Ecosystem Research Station under China State Forestry Administration, located in Jiangshan county $\left(28^{\circ} 32^{\prime} \mathrm{N}, 118^{\circ} 33^{\prime} \mathrm{E}\right)$, Zhejiang province. The PN plantations included three pure stands of native species ( $P$. massoniana) and exotic species ( $P$. elliottii and $P$. taeda). The sampled PN stands for these three species were even-aged planted forests. Among them, $P$. massoniana and $P$. taeda were surveyed in a 30-year-old stand, while $P$. elliottii was surveyed separately in four stands with different age, i.e., 3-yearold stand, 8-year-old stand, 18-year-old stand and 30-year-old stand. Thinning was applied in the 30-year-old stand to a target density ranging from about 1500 to 3000 stem ha ${ }^{-1}$. Finally, sampled SB forest was a typical secondary natural forest in subtropical areas of China that developed through 
Tab. 1 - The location, area and structural characteristics of the sampled forests.

\begin{tabular}{|c|c|c|c|c|c|c|c|}
\hline \multicolumn{2}{|c|}{ Species } & Forest Type & Location & $\begin{array}{c}\text { Density } \\
(\text { tree ha-1) }\end{array}$ & $\begin{array}{l}\text { Mean DBH } \\
(\mathrm{cm})\end{array}$ & $\begin{array}{c}\text { Age } \\
\text { (year) }\end{array}$ & $\begin{array}{l}\text { Area } \\
\text { (ha) }\end{array}$ \\
\hline \multicolumn{2}{|c|}{ Chinese fir } & Artificial, pure & $\begin{array}{l}\text { Fenyi, Jiangxi } \\
\left(27^{\circ} 34^{\prime} \mathrm{N}, 114^{\circ} 33^{\prime} \mathrm{E}\right)\end{array}$ & $1500-4800$ & 14.4 & Even-aged (27) & 34 \\
\hline \multirow{3}{*}{ Pine } & Pinus elliottii & \multirow{3}{*}{ Artificial, pure } & \multirow{3}{*}{$\begin{array}{l}\text { Ji'an, Jiangxi } \\
\left(27^{\circ} 03^{\prime} \mathrm{N}, 114^{\circ} 24^{\prime} \mathrm{E}\right)\end{array}$} & $1800-4200$ & $6.5-15.5$ & $\begin{array}{l}\text { Four even-aged stands } \\
\text { with age of 3-, 8-, 18- } \\
\text { and } 30 \text {-year-old }\end{array}$ & 65 \\
\hline & Pinus taeda & & & 1800 & 15.3 & Even-aged (30) & 53 \\
\hline & Pinus massoniana & & & 2200 & 12.5 & Even-aged (30) & 72 \\
\hline \multicolumn{2}{|c|}{ Moso bamboo } & Artificial, pure & $\begin{array}{l}\text { Fenyi, Jiangxi } \\
\left(27^{\circ} 34^{\prime} \mathrm{N}, 114^{\circ} 33^{\prime} \mathrm{E}\right)\end{array}$ & $2000-4500$ & 10.2 & Uneven-aged (1-9) & 35 \\
\hline \multicolumn{2}{|c|}{ Secondary broadleaved } & Natural, mixed & $\begin{array}{l}\text { Jiangshan, Zhejiang } \\
\left(28^{\circ} 32^{\prime} \mathrm{N}, 118^{\circ} 33^{\prime} \mathrm{E}\right)\end{array}$ & 3200 & 8.1 & Uneven-aged ( 6- 45) & 70 \\
\hline
\end{tabular}

natural regeneration after extensive deforestation in primary forests in the late 1970s. This forest received little disturbance from human thereafter, and naturally developed into an uneven-aged, mixed broad-leaved forest, with species mainly from the families of Fagaceae, Lauraceae, Aquifoliaceae and Theaceae. The information about the location, the area and structural characteristics of the sampled forests are summarized in Tab. 1.

\section{Measurements of mechanical damage}

This work is guided on "Observation Methodology for Long-term Forest Ecosystem Research" of National Standards of the People's Republic of China (GB/T 330272016). The total number of randomly established plots for the CF plantation, PN plantation, MB plantation, and SB forest were $15,38,36$, and 16 , respectively, with the plot size being $400 \mathrm{~m}^{2}(20 \times 20 \mathrm{~m})$ for PN and $\mathrm{MB}$ plantations, and $900 \mathrm{~m}^{2}(30 \times 30 \mathrm{~m})$ for CF plantation and SB forest. The number of the plots of $P$. massoniana, $P$. elliottii and $P$. taeda within PN plantations were 10 , 16 and 12, respectively. Considering the relevance of physical damage to tree stem strength, which is closely related to tree age, stand-age-based stratified sampling was conducted in P. elliottii stands. Four plots were established in the plantation for each age. To explore the effect of oleoresin tapping on tree damage, four plots were established in 30-year-old P. elliottii stand where oleoresin tapping had been applied to all the trees in the stand, and additional four plots, serving as the control, were established in 30-year-old nontapping plantation. Site altitude, slope, and tree/culm age were registered. Diameter at breast height (DBH) of each tree/culm in the plots was measured, with the minimum $\mathrm{DBH}$ being $5 \mathrm{~cm}$ for the plantation of $\mathrm{CF}$, $\mathrm{PN}$ and $\mathrm{MB}$, and $2 \mathrm{~cm}$ for the natural SB forest. The SB forest had different species with more trees in smaller sizes.

Tree/culm status was categorized as undamaged, bending, leaning, branch breakage, stem breakage, decapitation, and uprooting, according to tree/culm appearance after the ice storm. The definitions of these categories are as follows:
(1) Undamaged: no visible damage on trunk and branches.

(2) Bending: trunk bent; whole root system remains in soil but may become loosened or experiences no change.

(3) Leaning: trunk leaning toward the ground but not bent, root system still in soil.

(4) Branch breakage: tree trunk standing straight with broken branches on otherwise normal trees.

(5) Stem breakage: stem broken randomly below the crown.

(6) Decapitation: live crown is gone, but trunks stand firmly.

(7) Uprooting: root disc exposed and visible. One side of the root system still attached to soil, crown tops and branches may show different degrees of damage.

The category (1) was considered as normal growth and survived the ice storm unscratched. The categories (2) through (7) were treated as damaged trees/culms and surveyed in the corresponding damage types. The damage may be induced by a combination of ice, snow and wind which occurred simultaneously in the 2008 ice storm. However, ice was considered as the major contributor because the ice load persisted on the canopies longer than snow load did, as wind tended to blow away the snow from branches.

In forests with multi-storied canopies, understorey trees on slope often incline their trunks downwards even under normal conditions (Ishii \& Higashi 1997). In our survey, we confirmed a tree as bending damage or leaning damage only if the degree of bending or inclination was markedly higher than its neighbors.

\section{Statistical analysis}

For damage assessment, we used damage rate rather than mortality to represent the ice storm impact on forest trees, because some damage types (e.g., leaning, bending and branch breakage) did not necessarily lead to dead trees. The damage degree in a forest plot was expressed as damage rate, i.e., the percentage of the number of damaged trees to the total number of trees in the plot. Three types of damage rate were used for statistical analysis. Damage rate for a certain type was expressed as the percentage of the number of the trees with that specific damage type to the total number of trees in the survey plots. The overall damage rate was expressed as the percentage of the sum of all six damage types to the total number. The damage rate of stem breakage, decapitation and uprooting (abbreviated as SDU) was expressed as the percentage of the number of trees with the SDU damage types to the total number. We grouped the trees with SDU damage types as these trees would mostly perish in the following years, while those with the damage types of bending, leaning, and branch breakage will generally survive and get back to normal growth (Zhou et al. 2011b). Therefore, the SDU damage rate was more accurate to describe the long-term stand loss caused by the ice damage than the overall damage rate, which was more useful to show the general status of the ice damage to forests.

Pearson's Chi-square analysis was applied to assess the correlation between tree/ culm DBH class and damage rate of each damage type based on individual tree/culm data for CF, MB and SB. The correlation between age class of MB culm and damage rate for each damage type was also assessed using Chi-square analysis based on the individual culm data, because MB was an uneven-aged stand for which stand age was undefined. We calculated the difference in the damage rate of each damage type among age classes for Pinus elliottii using ANOVA analysis based on stand-level data. We also calculated the difference in the damage rate of each damage type between altitudes using ANOVA for CF and $M B$ plantations. A linear regression analysis was applied between the stand density and overall damage rate for CF and MB plantations. The effect of oleoresin tapping on the damage rate of each damage type was determined using ANOVA analysis for Pinus elliottii. In Chi-square analysis, the associated Pearson's Chi-square $\left(\chi^{2}\right)$ and asymptotic significance $(p)$ were calculated. Before ANOVA was applied, the data were screened using exploratory data analysis, 
Tab. 2 - Damage types and rate (\%) of four forest types in subtropical China following an ice storm event. Values and standard devia tion of damage rate are reported. Different letters within the same column indicate significant differences between values $(\mathrm{p}<0.05)$.

\begin{tabular}{|c|c|c|c|c|c|c|c|c|}
\hline \multicolumn{2}{|c|}{ Forest Types } & Bending & Leaning & $\begin{array}{l}\text { Branch } \\
\text { Breakage }\end{array}$ & $\begin{array}{c}\text { Stem } \\
\text { Breakage }\end{array}$ & Decapitation & Uprooting & Total \\
\hline \multicolumn{2}{|c|}{ CF Plantation } & $6.59 \pm 2.11^{a}$ & $5.21 \pm 1.80^{b}$ & - & $27.58 \pm 11.43^{\mathrm{ab}}$ & $21.62 \pm 10.34^{b}$ & $5.85 \pm 2.82^{b}$ & $66.84 \pm 13.32^{c}$ \\
\hline \multirow{3}{*}{$\begin{array}{l}\text { PN } \\
\text { Plantation }\end{array}$} & Pinus elliottii & $9.23 \pm 3.38^{a}$ & - & $5.78 \pm 2.87^{\mathrm{a}}$ & $32.39 \pm 10.36^{b}$ & - & $2.21 \pm 1.19^{\mathrm{a}}$ & $49.61 \pm 14.63^{b}$ \\
\hline & Pinus taeda & $11.18 \pm 3.29^{a}$ & - & $5.42 \pm 2.20^{\mathrm{a}}$ & $18.92 \pm 8.74^{a}$ & - & $1.13 \pm 0.82^{a}$ & $36.65 \pm 13.46^{a}$ \\
\hline & Pinus massoniana & $6.08 \pm 2.95^{a}$ & - & $5.41 \pm 2.19^{\mathrm{a}}$ & $12.49 \pm 2.85^{a}$ & - & $1.07 \pm 0.76^{\mathrm{a}}$ & $25.05 \pm 11.79^{a}$ \\
\hline \multicolumn{2}{|c|}{ MB Plantation } & $18.38 \pm 7.34^{b}$ & - & - & $23.10 \pm 11.86^{a b}$ & - & $15.11 \pm 11.54$ & $c 56.59 \pm 18.13^{b c}$ \\
\hline \multicolumn{2}{|l|}{ SB Forest } & $56.31 \pm 19.03^{c}$ & $1.20 \pm 1.03^{a}$ & - & $10.23 \pm 3.28^{a}$ & $8.50 \pm 2.95^{\mathrm{a}}$ & $4.34 \pm 1.86^{b}$ & $80.58 \pm 16.48^{d}$ \\
\hline
\end{tabular}

and data normality was tested using the Shapiro-Wilk test of normality. The homogeneity of variances of data was tested using Levene's test in ANOVA analysis. The means were compared using the least significant difference (LSD) test for differences in damage rate. Results were considered significant at $p<0.05$. Data were analyzed with SPSS ${ }^{\circledast}$ program V.18 (SPSS Inc., IBM, Chicago, IL, USA).

\section{Results}

\section{Damage type and rate}

The 2008 ice storm caused massive damage to forests in the subtropical area of China. Ice storm damage on forest trees had a variety of types, including bending, leaning, branch breakage, stem breakage, decapitation, and uprooting (Tab. 2). Bending, stem breakage, and uprooting were the most frequent types, and occurred in all forest types we surveyed. Branch breakage occurred only in PN plantations, which were characterized by wide crowns and comparatively large branches. Leaning and decapitation occurred in CF plantation and SB forest, but not in other forests.

The overall damage rate $( \pm S E)$ for the forests we surveyed varied between $25.05 \% \pm 11.79 \%$ and $80.58 \% \pm 16.48 \%$, with the highest rate occurring in SB forest (80.58\%), followed by CF plantation (66.84\%) and MB plantation (56.59\% - Tab.
). PN plantation had a comparatively low damage rate, with the overall damage rate for P. elliottii, P. taeda and P. massoniana being $49.61 \%, 36.65 \%$ and $25.05 \%$, respectively. The overall damage rate for SB forest was significantly higher than those for other forests, indicating that the SB forest was the most extensively damaged by the ice storm. CF plantation was more extensively damaged than PN plantation.

In terms of SDU damage rate, the most severely damaged forest type was CF plantation (55.04\%), followed by MB plantation (38.21\%) and P. elliottii plantation (34.60\%). SDU damage rate of SB forest was only $23.07 \%$, even though its overall damage rate was the highest, indicating that the long-term impact on SB forest was not as severe as on CF plantation and MB plantation, and was even less than $P$. elliottii plantation.

\section{Damage related to tree/culm size}

Chi-square analysis showed that there was a significant association between the tree/culm DBH class and the ratio of the tree number within each damage type to the total damaged tree number (Tab. 3), implying that a tree/culm of different size has different vulnerability to ice storm within each damage type. CF stems with small size $(\mathrm{DBH}<10 \mathrm{~cm})$ were more likely to suffer from leaning (accounting for $31.16 \%$ ) and uprooting (accounting for $29.71 \%$ ). CF with medium size (DBH between 10 and 20 $\mathrm{cm}$ ) or large size $(\mathrm{DBH}>20 \mathrm{~cm})$ was more likely to suffer from decapitation (accounting for $30.26 \%$ and $76.60 \%$, respectively) and stem breakage (accounting for $45.48 \%$ and $19.15 \%$, respectively). Among the damaged CF, the SDU damage rate for small-, medium- and large-sized trees was $57.27 \%$, $83.32 \%$ and $96.46 \%$, respectively, implying that ice storm damage on CF would get more severe as the DBH increased $\left(\chi^{2}=\right.$ 224.9, $p<0.001$ ).

For $\mathrm{MB}$ plantation, small-sized $(\mathrm{DBH}<8$ $\mathrm{cm}$ ) culms were more susceptible to the damage types of bending (accounting for 41.35\%) and stem breakage (accounting for 41.35\%). In contrast, large-sized ( $\mathrm{DBH}>12$ $\mathrm{cm}$ ) culms were more susceptible to stem breakage (accounting for $48.4 \%$ - Tab. 3). As the culm DBH increased, the rate of bending decreased $\left(X^{2}=164.57, p=0.001\right)$. Accordingly, the SDU rate (stem breakage and uprooting combined here) went up $\left(\chi^{2}=113.19, p=0.053\right)$, suggesting that large bamboo suffered ice damage more severely than small-sized bamboo culms.

Similar to $\mathrm{CF}$ and $\mathrm{MB}$, small-sized $(\mathrm{DBH}<5$ $\mathrm{cm})$ SB was more vulnerable to bending (accounting for $44.32 \%$ ) and leaning (accounting for $27.9 \%$ ), while the large-sized was more vulnerable to decapitation (accounting for $33.35 \%$ ) and uprooting (accounting for $27.86 \%)$. As the $D B H$ increased, the SDU rate increased $\left(X^{2}=197.62\right.$,

Tab. 3 - Percentage of tree/culm number with each damage type in the total number of damaged tree/culm for Chinese fir plantation, moso bamboo plantation and secondary mixed broadleaved forest.

\begin{tabular}{|c|c|c|c|c|c|c|c|c|}
\hline \multirow[b]{2}{*}{$\begin{array}{l}\text { Forest } \\
\text { Types }\end{array}$} & \multirow[b]{2}{*}{$\begin{array}{l}\text { Tree/Culm Size } \\
\text { (cm) }\end{array}$} & \multicolumn{5}{|c|}{ Damage Types } & \multirow[b]{2}{*}{$\begin{array}{c}\text { SDU } \\
\text { Combined }\end{array}$} & \multirow[b]{2}{*}{ Total } \\
\hline & & Bending & Leaning & $\begin{array}{c}\text { Stem } \\
\text { breakage }\end{array}$ & Decapitation & Uprooting & & \\
\hline Chinese & Small $(\mathrm{DBH}<10)$ & 11.59 & 31.16 & 17.40 & 10.14 & 29.71 & 57.25 & 100.00 \\
\hline \multirow[t]{4}{*}{ Fir } & Medium $(10 \leq \mathrm{DBH} \leq 20)$ & 10.42 & 6.26 & 45.48 & 30.26 & 7.58 & 83.32 & 100.00 \\
\hline & Large $(\mathrm{DBH}>20)$ & 2.12 & 1.42 & 19.15 & 76.60 & 0.71 & 96.46 & 100.00 \\
\hline & $\chi^{2}-1-2$ & 83.21 & 254.81 & 131.95 & 187.32 & 309.83 & 224.90 & - \\
\hline & prob & 0.001 & $<0.001$ & 0.001 & $<0.001$ & $<0.001$ & $<0.001$ & - \\
\hline Moso & Small $(\mathrm{DBH}<8)$ & 41.35 & - & 41.35 & - & 17.30 & 58.65 & 100.00 \\
\hline \multirow[t]{4}{*}{ Bamboo } & Medium $(8 \leq \mathrm{DBH} \leq 12)$ & 33.01 & - & 38.84 & - & 28.15 & 66.99 & 100.00 \\
\hline & Large $(\mathrm{DBH}>12)$ & 26.20 & - & 48.40 & - & 25.40 & 73.80 & 100.00 \\
\hline & $x^{2}=100$ & 164.57 & - & 108.93 & - & 122.81 & 113.19 & - \\
\hline & prob & 0.001 & - & 0.065 & - & 0.025 & 0.053 & - \\
\hline Secondary & Small $(\mathrm{DBH}<5)$ & 44.32 & 27.90 & 4.10 & 12.18 & 11.50 & 27.78 & 100.00 \\
\hline \multirow[t]{4}{*}{ Forest } & Medium $(5 \leq \mathrm{DBH} \leq 10)$ & 12.04 & 22.62 & 21.90 & 22.81 & 20.63 & 65.34 & 100.00 \\
\hline & Large $(\mathrm{DBH}>10)$ & 6.40 & 18.67 & 13.72 & 33.35 & 27.86 & 74.93 & 100.00 \\
\hline & $\chi^{2}$ & 265.85 & 155.29 & 98.96 & 222.82 & 167.52 & 197.62 & - \\
\hline & prob & $<0.001$ & 0.008 & 0.015 & 0.001 & 0.007 & 0.002 & - \\
\hline
\end{tabular}


$\mathrm{p}=0.002$ ), implying that large trees were more vulnerable to severe damage caused by ice storm.

\section{Damage related to stand/culm age}

The ice damage varied with stand age in P. elliottii plantation (Fig. 2). For young trees, the highest damage type was bending, with $55.32 \%$ occurring in the 3 -year-old stand, significantly higher than other age classes. Bending damage rate in the 8-yearold stand and 18-year-old stand was significantly higher than that in the 30-year-old stand. For the 18-year-old and 30-year-old stand, stem breakage was the highest damage type, with its percentage in 18-yearold trees (34.03\%) significantly higher than other age classes. Stem breakage rate for 30-year-old trees (18.09\%) was significantly higher than the 3-year-old and 8-year-old. Three-year-old P. elliottii was the most extensively damaged by the ice storm, with an overall damage rate of $55.32 \%$, followed by the 18-year-old trees with a slightly lower overall damage rate of $53.73 \%$. The 18-year-old trees were the most severely damaged, with the highest SDU damage rate of $37.43 \%$.

In MB plantation, the disparity in damage rate among the age class seemed not to be as wide as in pine plantation (Tab. 4). Among the three damage types, only the uprooting damage rate was found to be significantly correlated with the culm age class $\left(\chi^{2}=92.14, p=0.035\right)$. A mature culm was more likely to suffer from uprooting, while a younger culm was more likely to suffer from bending and stem breakage.

\section{Damage related to stand density}

Stand density is an important factor affecting forests' susceptibility to ice storm damage. A linear regression between stand density and overall damage rate revealed that the overall damage degree went up linearly with increased stand density for $C F$ plantation $\left(R^{2}=0.283\right)$ and bamboo stand

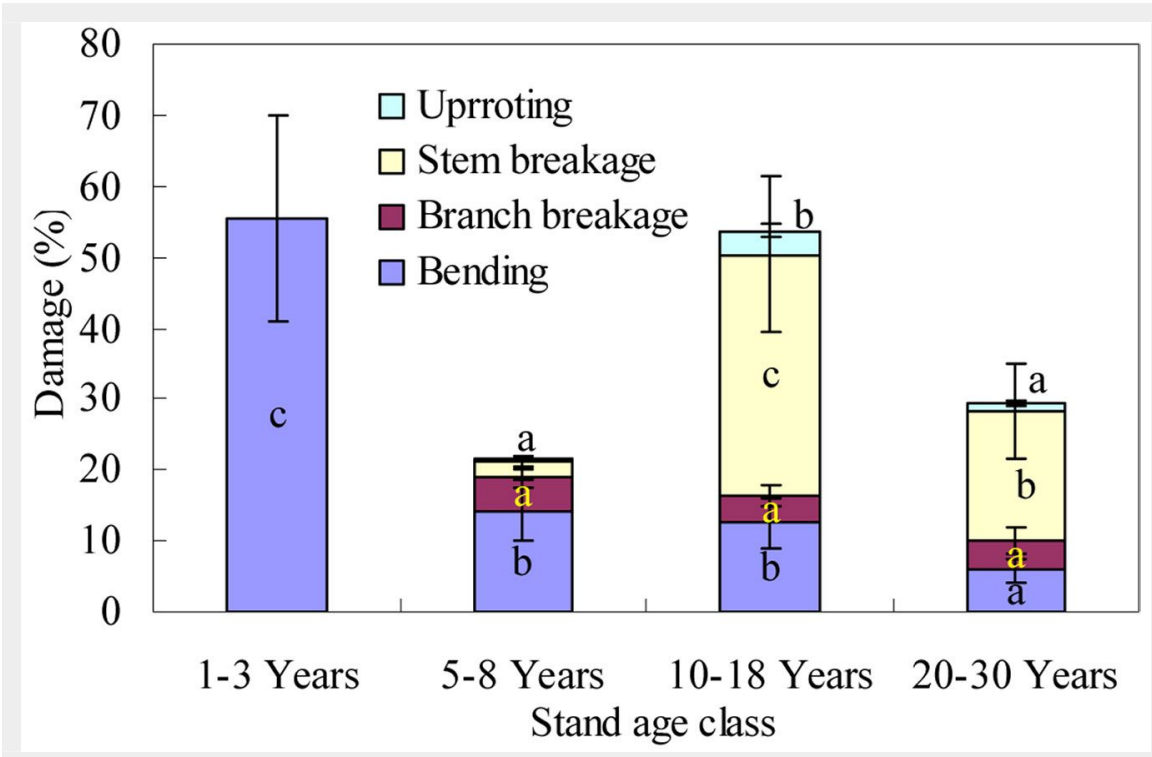

Fig. 2 - Damage type and percentage of Pinus elliottii plantation in relation to age classes. Different letters within the same pattern (same colour) indicate significantly different damage percentages $(p<0.05)$.

Tab. 4 - Percentage of culm number with each damage type in the total number of damaged culm for Moso bamboo plantation.

\begin{tabular}{lcccc}
\hline Culm Age & Bending & Stem breakage & Uprooting & Total \\
\hline 1-2 years & 35.05 & 41.81 & 23.14 & 100 \\
3-4 years & 27.57 & 53.77 & 18.66 & 100 \\
5-6 years & 31.84 & 33.41 & 34.75 & 100 \\
$>7$ years & 34.00 & 28.67 & 37.33 & 100 \\
$\chi^{2}$ & 14.51 & 48.13 & 92.14 & - \\
prob & 0.081 & 0.058 & 0.035 & - \\
\hline
\end{tabular}

$\left(R^{2}=0.228\right.$ - Fig. 3). The linear regression Damage related to site altitude between the stand density and overall damage caused by an ice storm was statistically significant for both CF and MB plantation ( $p=0.042$ and $p=0.003$, respectively). A denser plantation suffered from ice damage more extensively than a less densely populated stand.
Tree damage induced by ice storm varied significant differences in the overall damage rate, stem breakage rate and decapitation rate between the low altitude $(250 \mathrm{~m}$ a.s.I.) and high altitude (500 $\mathrm{m}$ a.s.l.) in CF plantation. The total damage, stem breakage and decapitation occurred more heavgreatly at different altitudes. There were

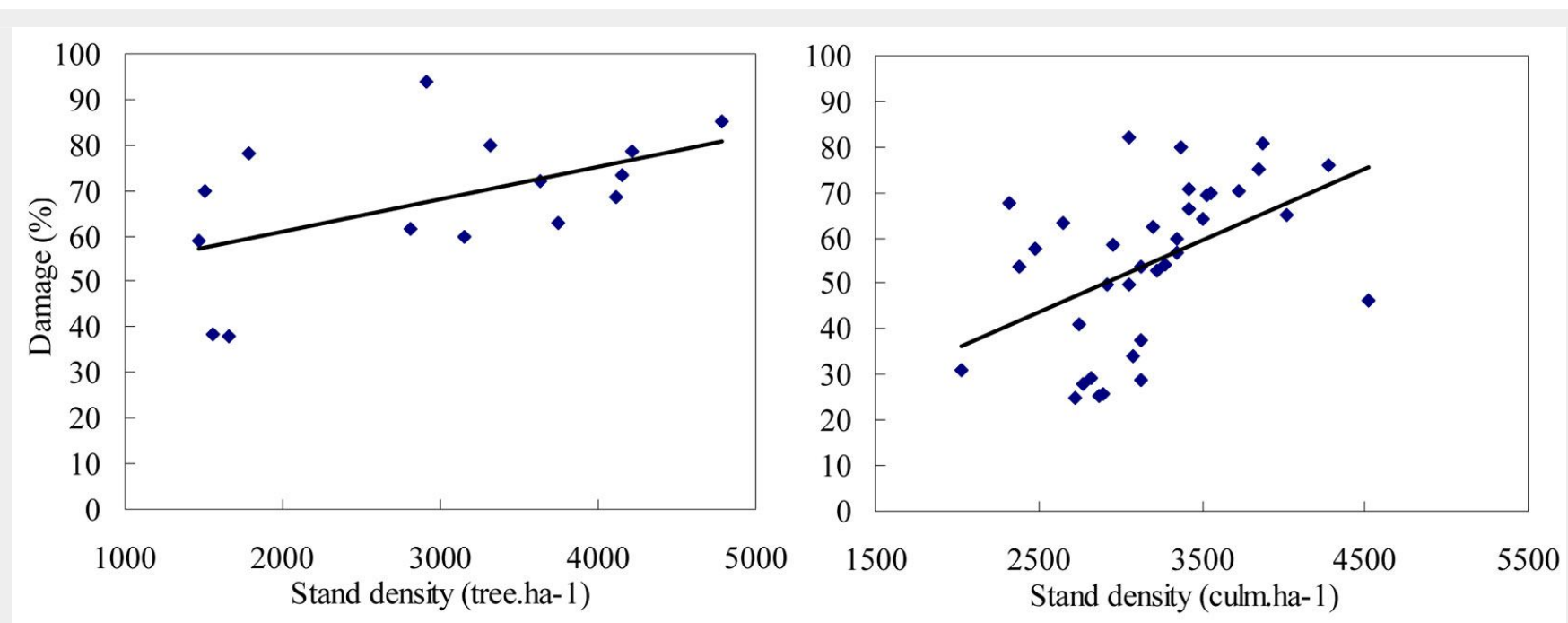

Fig. 3 - Linear regression between stand density and overall damage percentage for Chinese fir plantation (left) and Moso bamboo plantation (right). 

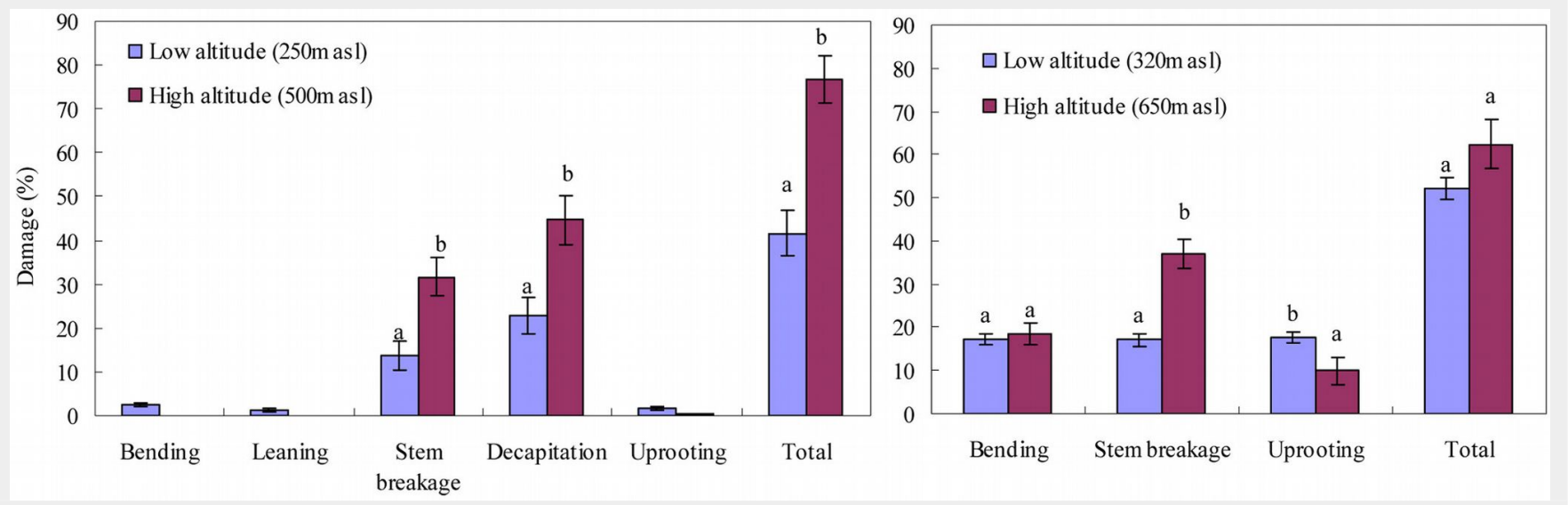

Fig. 4 - Damage type and percentage of Chinese fir plantation (left) and Moso bamboo plantation (right) at the sites with low and high altitudes. Different letters within the same pattern indicate significantly different damage percentages $(p<0.05)$.

ily at high altitudes than at low altitudes (Fig. 4). CF trees at high altitudes were more susceptible to damage resulting from an ice storm.

For MB plantation, a high altitude tended to result in aggravated ice damage to bamboo culms (overall damage rate of $62.34 \pm$ 5.72 at $650 \mathrm{~m}$ a.s.l. vs. $52.06 \pm 2.47$ at $320 \mathrm{~m}$ a.s.l.), but the difference was not statistically significant ( $F=2.702, p=0.11$ - Fig. 4). Similar to $C F$ plantation, stem breakage rate at high altitudes was significantly higher than at low altitudes. On contrary, uprooting rate was significantly lower than at high altitudes.

\section{Damage related to oleoresin tapping on P. elliottii}

Oleoresin tapping, a common practice in pine plantations for obtaining non-timber product, aggravated ice damage on $P$. elliottii trees. The overall damage rate of $P$. elliottii with oleoresin tapping was significantly higher than that without oleoresin tapping ( $54.65 \% \pm 7.16 \%$ vs. $29.00 \% \pm 3.30 \%$ ). Oleoresin tapping led to a significant in- crease of stem breakage, which was over six times higher than the control (Fig. 5). However, there were no significant differences in damage rate between oleoresin tapping and the control for other damage types. Oleoresin tapping dramatically reduces the mechanical strength of the stem, decreasing its resistance to ice damage.

\section{Discussion}

\section{Tree's susceptibility to ice damage}

Susceptibility to physical ice damage is affected by crown exposure to ice and snow, and appears to be strongly species-specific (Abell 1934, Lemon 1961, Whitney \& Johnson 1984). However, studies often disagree on which types of species are the most susceptible to ice damage. Some research has demostrated that coniferous species are more susceptible to ice damage (Whitney \& Johnson 1984) while other research has shown that broadleaved trees are more likely to be damaged by ice storms (Abell 1934). In our study, the broadleaved trees (SB forest) received more damage than

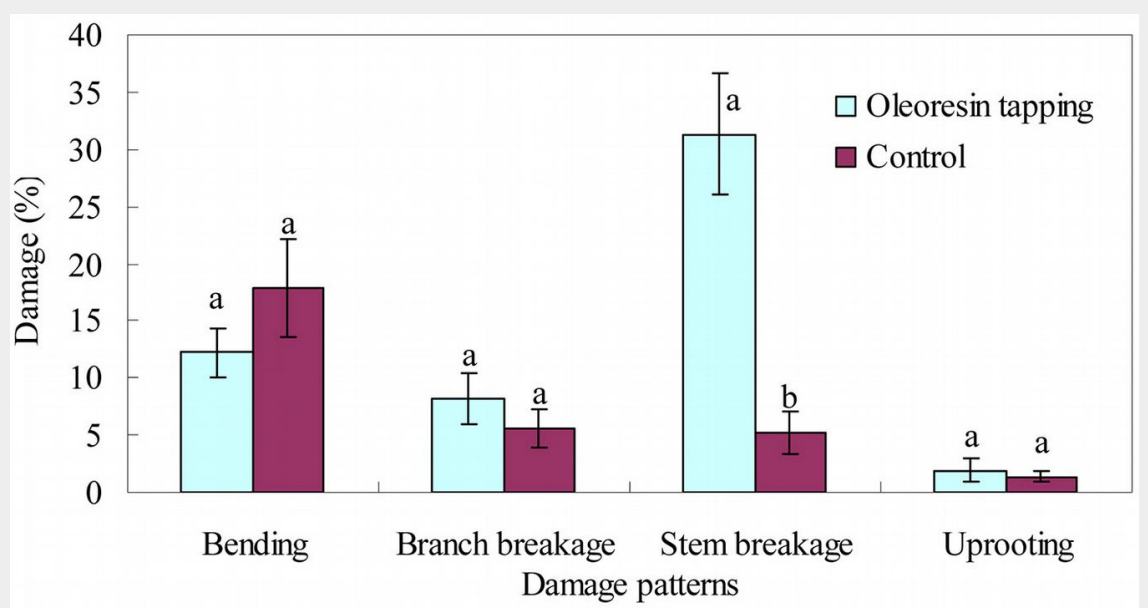

Fig. 5 - Damage type and percentage (\%) of P. elliottii in relation to oleoresin tapping on $P$. elliottii trees. Different letters within the same pattern indicate significantly different damage percentages $(p<0.05)$. conifer plantations ( CF and PN) or MB plantation, which might result from their broad, flat crowns that expose a large surface area of branches and therefore make them more susceptible to extensive damage. With compact, cone shaped crowns, $\mathrm{CF}, \mathrm{PN}$ and $\mathrm{MB}$ expose a smaller proportion of their lateral branches to ice accumulation and snow load (Bruederle \& Stearns 1985, Hauer et al. 1993), resulting in less physical damage than SB. On the other hand, SB had a lower damage severity (a lower SDU damage rate) than CF, MB and $P$. elliottii plantation, although it had the highest overall damage rate. The multi-species composition and multi-layer structure could have prevented SB from suffering more serious damage types such as stem breakage, decapitation and uprooting.

$P$. massoniana plantation was the least damaged by the ice storm, either in terms of overall or SDU damage rate, exhibiting higher resistance to ice storm than $P$. elliottii and $P$. taeda. The exotic species are cultivated widely in southern China since they were introduced into this country around 1930 due to their fast-growth and highyield, and have been recognized as a successful case of exotic tree introduction (Zhou et al. 2011c). Facing such extreme disturbance as the 2008 ice storm, the exotic pines presented higher vulnerability than native pine ( $P$. massoniana).

Another exotic tree species which was severely damaged in this ice storm was the eucalyptus (Xu et al. 2008). Introduced from Australia, the eucalyptus was well received because of its fast growth and high productivity, like the exotic pine. Unfortunately, these species were overwhelmingly destroyed in the 2008 Chinese ice storm. Although they may grow well under normal weather and climate conditions, nonnative species are more vulnerable to extreme natural events like large ice storms. Therefore, it is essential to balance between high productivity under normal conditions and survivability under extreme conditions when foreign tree species are introduced. 
Factors affecting ice damage severity

Tree size was an important factor in determining its susceptibility to ice damage (Rhoads et al. 2002, Wang et al. 2009, Su et al. 2010, Man et al. 2011, Nadrowski et al. 2014). Many studies reported that larger trees received more damage from ice storms (Platt et al. 2000, Nielsen et al. 2003, Su et al. 2010, Man et al. 2011). The proportion of trees leaning or bending was generally high in small size classes, while that of uprooting or breakage was high in intermediate and large size classes (Yorks \& Adams 2005, Wang et al. 2009, Su et al. 2010). Man et al. (2011) reported that bending, leaning, and uprooting occurred more likely on small-sized trees in evergreen broad-leaved forests in China. However, other researchers gave contrasting results concerning the relationship between damage and tree diameter. Belanger et al. (1996) found no difference in damage to loblolly pines of different size classes following an ice storm. Ryall \& Smith (2005) observed that large diameter trees were less damaged by ice accumulation than small diameter trees. Therefore, it is necessary to consider more factors, such as tree species, age, development stage and health condition, when the role of tree size is assessed in determining its resistance to ice storms.

In our study of CF plantation, MB plantation and SB forest, a large-sized tree/culm was more likely to suffer from severe damage types (stem breakage, decapitation, or uprooting), while a small-sized one was more likely to bend or lean. The forests we surveyed ( $C F$ and $S B$ ) in this study were pretty young (mostly less than 30 years), and the tree size probably did not yet attain to the maximum under the climate and site condition. Therefore, the large size class in our study probably could not present the real large size. Studies on tree size effect on ice damage are needed in the forests with wider span of tree size.

Tree age is closely correlated with the mechanical strength, flexibility, and heath status. Mature or overmature trees are more likely to be partially decayed, or attacked by insects, pests, or pathogens, which deteriorates the mechanical properties and increases the susceptibility to damage from ice and wind (Bruederle \& Stearns 1985). The juvenile $P$. elliottii has a more flexible stem than old growth, resulting in a higher susceptibility to bending, while the old growth, with a rigid stem and possibly a poor health status, would easily break under the ice and snow load.

For moso bamboo, with a much shorter lifetime and narrower age class span than woody arbor tree, the difference in overall damage rate among ages was not as great as $P$. elliottii. A younger culm was more likely to suffer from bending and stem breakage. With the increase of culm age, the rate of stem breakage declined, while the uprooting rate went up except for the one- to two-year-old culm, which was a lit- tle higher than those aged three to four years. Unlike other woody trees, bamboo culms maintain a constant shape in their lifetime, because they complete their radial and apical growth within their first growing season, reaching full diameter and height in a matter of two to three months (Zhou et al. 2005). The resistance of bamboo culms to ice damage is more correlated with the extent of lignification than their DBH or health status. Since younger culms were less lignified than the older ones, they were more susceptible to stem breakage. On the other hand, the more lignified culms were more susceptible to uprooting damage than to bending or stem breakage due to their less flexibility. For bending damage, the youngest culms present the highest bending rate because of their lowest level of lignification and high flexibility (Zhou et al. 2011b).

Plantation stand density was proven to be closely related with ice or snow damage. Ryall \& Smith (2005) reported a strong positive relationship between crown damage and stand density for red pine (Pinus resinosa) plantations in Eastern Ontario, damaged by the 1998 ice storm. Cremer et al. (1982) observed that overstocked or dense plantations suffered more severe damage than more widely spaced plantations with trees characterized by sturdier boles and well-developed canopies. However, other researchers found no relationship between the stand density and severity of damage (Amateis \& Burkhart 1996).

In CF and MB plantations, high stand density causes lower light levels under the canopy and stimulates height growth of the tree/culm to reach high light levels above the canopy (Sterck \& Bongers 1998). This results in slender trees/culms in plantations, which were proven to be more susceptible to ice and snow damage (Päätalo et al. 1999). In dense plantations, the tree crowns may overlap, and ice and snow can accumulate to form thick mats on top of the overstory canopy. As a result, the entire canopy may collapse once the load becomes too heavy. Harrington \& DeBell (1996) described similar findings in young, dense hybrid poplar plantations.

The $\mathrm{CF}$ and $\mathrm{MB}$ plantation in our study were relatively dense, with a stand density varying from 1500 to 5000 stem ha ${ }^{-1}$. The tendency of damage rate to increase with stand density differed from some other forests with lower density. A negative linear correlation between stand density and damage rate was presented in the secondary montane forest with a stand density ranging between 300 and 1300 stem $\mathrm{ha}^{-1}$ (Zhu et al. 2006). The study on CF damage caused by the 2008 ice storm in Guangdong province indicated that both low density (<1500 stem ha-1) and high density (>3500 stem ha ${ }^{-1}$ ) increased ice damage ( $\mathrm{He}$ et al. 2010). It seems that there exists a nonlinear relationship between stand density and damage rate. The disturbance severity can exhibit an inconsistent trend as the stand density changes in a different range. It is suggested to cover the density range as widely as possible when one investigates the changing trends of disturbance severity with stand density.

Many researchers have noted that forests at higher altitudes could have a higher risk of damage from snow and ice (Rhoads et al. 2002, Valinger \& Lundqvist 1992). The snow- and wind-induced damage increased with the elevation in a montane secondary forest in Northeastern China (Zhu et al. 2006). Damage to the mature forests increased with elevation following an ice storm in American northern hardwoods (Rhoads et al. 2002). Our study on CF and MB plantations confirmed these reports. Trees/bamboos at higher altitudes experienced a longer duration of snow and ice load after an ice storm because of lower temperature and exposure to stronger wind, leading to more damage. Heavier snowfall at higher altitudes might be another reason for the observation that trees/bamboos received more damage at high than low altitudes. There were some opposite results in the literature, however. Ice damage was less severe at low than high altitudes in evergreen broad-leaved forests in Gutianshan, China (Man et al. 2011). Thus, altitude effects on ice damage may vary from site to site.

\section{Implications for forest management}

Ice storm damage to forests is affected by many factors, including stand characteristics, tree features, topography and site conditions. To alleviate, or even avoid this type of damage, it is necessary to apply correct silvicultural operations and management measures.

"Matching species with the site", the principal criterion in tree planting, should be given a priority consideration when climate uncertainty is of concern. "Matching species with the site" has been known as the baseline in traditional forest silviculture, which provides a prerequisite for trees to grow normally and to achieve an expected production. This criterion seems even more important in forest planting in a climate change scenario. It plays a pivotal role in whether trees can survive an extreme meteorological disturbance. Many studies have showed that forest resistance to extreme ice damage varies with species and site conditions. In our study, the overall damage rate for $\mathrm{CF}$ at $500 \mathrm{~m}$ a.s.l. was almost twice that at $250 \mathrm{~m}$ a.s.l., and mainly resulted from stem breakage and decapitation (Fig. 4). Stem breakage rate for $M B$ at $650 \mathrm{~m}$ a.s.l. was twice that at $320 \mathrm{~m}$ a.s.l. also, implying ice damage severity for some plantations ( $C F$ and $M B$ ) is highly sensitive to altitude. Risk of ice damage should be carefully assessed before CF afforestation is carried out at high altitudes in subtropical areas of China.

Mixed multi-layer forests should be promoted in meteorologically sensitive regions. With multi-species composition and 
multi-layer structure, mixed forests exhibit a higher stability to natural disturbance than pure plantations. In our study, although the SB forest received extensive damage in the ice storm, the damage was mainly characterized as bending (56.31\% Tab. 2), which does not cause sustained damage to the forest structure. Schütz et al. (2006) also reported that a mixture of $10 \%$ of broadleaved trees or wind-firm conifers like Douglas fir greatly reduced spruce vulnerability to winter storm "Lothar". Mixed forests can be established at the initial stage in afforestation, but also can be achieved at the stage of tending operations (Schütz et al. 2006).

A cautious risk assessment should be taken when exotic species are planned for large-scale afforestation on the sites prone to the attack from extreme meteorological events. Exotic species or varieties are usually introduced in anticipation of high production and good economic benefits. However, an extreme natural event for several days could destroy the whole plantations achieved for decades, resulting in heavy losses economically and ecologically. In the 2008 Chinese ice storm, the exotic pine species ( $P$. elliottii and $P$. taeda) received much more damage than native pine ( $P$. massoniana), and the eucalyptus was almost completely wiped out, as mentioned above. Therefore, it is necessary to consider not just high productivity but also species resistance to extreme climatic events. As a general principle, local species should be given the highest priority in large-area plantation (Zhou et al. 2011a).

Thinning and selective cutting for the timber-oriented plantations are suggested to be applied in time. Thinning, a commonlyconducted measure in even-aged pure plantation in China, could increase the resistance to ice damage by encouraging the development of sturdier stems with stronger branches (Morris \& Ostrofsky 2005). Many studies have observed that thinned stands presented a lower vulnerability to ice storm than unthinned counterparts (Bragg \& Shelton 2010). Thinned stands can also undergo faster recovery after a storm (Morris \& Ostrofsky 2005). Our study showed that middle-aged or mature trees were more vulnerable to severe damage types. Therefore, timely selective cutting of mature or over-mature large-sized trees is probably a good management measure for some timber-oriented plantations. This measure can help not only to increase economic income, but also to avoid potential damage from unpredictable extreme disturbance. Our finding in this study that damage rate increases with stand density also provides indirect evidence supporting the conclusion that thinning or selective cutting could reduce ice damage.

Non-timber products should be extracted only after the risk of extreme events are carefully considered. Worldwide, non-timber products from forests provide continu- ous sources of income for villagers and are essential for combating deforestation and promoting reforestation (FAO 2009). However, non-timber products should not be exploited at the cost of increased risk to storm damage. Oleoresin tapping is one of the most common non-timber production practices in China and other developing countries. As showed in our research, pine trees with oleoresin tapping suffered a much higher degree of damage than those under normal conditions. Excessive extraction of pine oleoresin jeopardizes tree survivability in extreme events. Oleoresin tapping usually leads to excessive bark cuts in stems, with nearly half of the stem circumference removed. These excessive cuts may not lead to tree death under normal conditions, but exacerbate mechanical instability of pine trees under storms. Hence, planning for sustainable extraction of nontimber products should be an integral part of the governing strategy for the long-term use of forest resources to accommodate the risk of extreme events (Zhou et al. 2011c). New tapping methods should be used if oleoresin tapping cannot be completely prohibited in pine plantations. Instead of bark chipping, using the borehole method could be a better choice for oleoresin tapping, as it is based on boring holes into the sapwood xylem of pine trees, thus minimizing the physical and physiological damage to the stems (Hodges \& Johnson 1997). In addition, by using oleoresin inducer, the oleoresin exudation can remain stable even if the cut does not reach the xylem (Guo et al. 2012), which reduce the physical damage to the pine stems. With the improvement of tapping techniques, a balance can be found between extra economic income from nontimber products and avoidance of severe damage from extreme conditions.

Salvage logging should be carefully operated to minimize further disturbance to forest recovery process following the ice storm. Salvage logging is an operation to harvest downed wood in forest stands impacted by a natural disturbance such as ice storm, fire, insect outbreak or windthrow. Even if such salvage logging is broadly publicly accepted (Lindenmayer et al. 2004), it is highly controversial whether salvage logging should be conducted and what the best practice is if it is proceeded (Stokstad 2006). Cooper-Ellis et al. (1999) indicated that salvage logging following wind disturbance might have serious longterm implications. Irland (2000) suggested that the damage caused by sloppy salvage logging could exceed the damage caused by the storm in some stands. However, salvage logging can help reduce the risk of forest fires, forest pests and diseases and thus minimize economic loss. For such massive natural disturbance as the 2008 China ice storm, a balanced strategy should be adopted in post-disturbance recovery measures. Our study has shown that although the natural forests suffered ice damage as extensively as in plantations, the damage was mostly characterized by a lower severity, such as bending, leaning and branch breakage. The trees with these damage types were expected to survive. Thus, major post-storm intervention seems to be unnecessary, and salvage logging is not recommended in this forest. Another reason for the exclusion of salvage logging in natural forests is that they usually grow in high ecologically sensitive areas, and cannot afford a second disturbance. The third reason is that the SB forests, located usually at higher elevations or on mountain tops in remote areas (Shao et al. 2011), are difficult to access for loggers, which will increase the costs of salvage logging. For the plantations of $C F, P N$ and $M B$, which are oriented to timber production, their stand structure almost collapsed in this ice storm. Consequently, appropriate human intervention might help to facilitate their recovery. Salvage logging can be carried out, but should be targeted carefully at the severely damaged trees which will not survive this event definitely.

Extreme climatic events like the 2008 ice storm in China usually occur suddenly and unpredictably, and it is difficult to experiment on such events. Therefore, it is necessary in the future to make a full use of the "natural laboratory" provided by extreme events and explore their impact on natural ecosystems through case studies. However, since forests' resistance to large scale natural disturbance is affected by many factors that may interact with each other, recommendations for forest management based on separate analysis in one case can be biased. Integrated analysis and more case studies are needed.

\section{Conclusions}

The 2008 ice storm brought extensive damage to subtropical forests in China. Ice damage was characterized with a variety of patterns, i.e., bending, leaning, branch breakage, stem breakage, decapitation, and uprooting. The secondary broadleaved forest was damaged most extensively, with the highest overall damage rate, while Chinese fir plantation suffered the most severe long-term damage, with the highest rate of stem breakage, decapitation, and uprooting combined (55.04\%). Tree/culm size, age, stand density, site altitude, and management measures all have effects on ice storm damage. Large-sized trees/culms are more vulnerable to the damage types of stem breakage, decapitation and uprooting, while less severe damage types, such as bending and leaning, are more likely to occur in small-sized trees. Mature trees tend to be more vulnerable to severe damage types. High stand densities and high altitudes lead to significant increase in damage rates, whereas oleoresin tapping aggravates the damage to pine trees. The 2008 Chinese ice storm provided an opportunity for a case study on the impacts of extreme natural events on forests and 
other natural ecosystems. Forest silviculture and management practices can play significant roles in controlling forest susceptibility to extreme events.

\section{Acknowledgments}

This research was supported financially by Non-profit Industry Special Fund of State Forestry Administration of China (Grant 201204101), the Lecture and Study Program for Outstanding Scholars from Home and Abroad (Grant CAFYBB2011007), and Chinese Academy of Forestry (grants CAFYBB2008006 and RISF060701). This work is also supported by CFERN \& Beijing Techno Solutions Award Funds on excellent academic achievements. The authors thank the anonymous reviewers for their insightful and detailed comments on this manuscript. The comments have helped to shape this paper and clarify ambiguous sections in the former versions.

\section{References}

Abell CA (1934). Influence of glaze storm upon hardwood forests in the southern Appalachians. Journal of Forestry 32: 35-37.

Amateis RL, Burkhart HE (1996). Impact of heavy glaze in a loblolly pine spacing trial. Southern Journal of Applied Forestry 20: 151-155. [online] URL: http://www.ingentaconnect.com/content/ saf/sjaf/1996/000000020/00000003/arto0008

Belanger R, Godbee J, Anderson R, Paul J (1996). Ice damage in thinned and nonthinned loblolly pine plantations infected with fusiform rust. Southern Journal of Applied Forestry 20: 136142. [online] URL: http://www.ingentaconnect. com/content/saf/sjaf/1996/00000020/0000000 3/artoo005

Bragg DC, Shelton MG, Zeide B (2003). Impacts and management implications of ice storms on forests in the southern United States. Forest Ecology and Management 186: 99-123. - doi: 10.1016/S0378-1127(03)00230-5

Bragg DC, Shelton MG (2010). Recovery of planted loblolly pine 5 years after severe ice storms in Arkansas. Southern Journal of Applied Forestry 34 (1): 13-20. [online] URL: http://www.treesearch.fs.fed.us/pubs/downloa d/36143.pdf

Bruederle LP, Stearns FW (1985). Ice storm damage to a southern Wisconsin mesic forest. Bulletin of the Torrey Botanical Club 167-175. [online] URL: http://www.jstor.org/stable/2996 413

Cremer K, Borough C, McKinnell F, Carter P (1982). Effects of stocking and thinning on wind damage in pine plantations. New Zealand Journal of Forestry Science 12: 244-268. [online] URL: http://citeseerx.ist.psu.edu/view doc/download?doi=10.1.1.713.1711\&rep=rep1\&ty pe=pdf

Cooper-Ellis S, Foster DR, Carlton G, Lezberg A (1999). Forest response to catastrophic wind: results from an experimental hurricane. Ecology 80: 2683-2696. - doi: 10.1890/0012-9658 (1999)080[2683:FRTCWR]2.0.CO;2

FAO (2009). State of the world's forests. Food and Agriculture Organization of the United Nations, Rome, Italy, pp. 147.

Guo ZW, Zeng GL, Peng ZL, Zheng XC, Liu DC
(2012). Study on resin tapping technology of Pinus elliottii with cortical horizontal streaks. Jiangxi Journal of Forestry Science and Technology 2: 2-7. [online] URL: http://en.cnki.com. cn/Article en/CJFDTOTAL-JXLI201202002.htm Harrington CA, DeBell DS (1996). Above- and below-ground characteristics associated with wind toppling in a young Populus plantation. Trees 11: 109-118. - doi: 10.1007/PLoooog655 Hauer RJ, Wang W, Dawson JO (1993). Ice storm damage to urban trees. Journal of Arboriculture 19: 187-193. [online] URL: http://www. hilltowntreeandgarden.com/pdf/ice-storm-dam age-urban-trees.pdf

He Q, Li J-Y, Chen X-Y, Chen H-Y, Peng H-G, Fan S$J$ (2010). Types and extent of damage to Cunninghamia lanceolata plantations due to unusually heavy snow and ice in southern China. Chinese Journal of Plant Ecology 34: 195-203. - doi: 10.3773/j.issn.1005-264x.2010.02.011

Hodges AW, Johnson JD (1997). Borehole oleoresin production from slash pine. Southern Journal of Applied Forestry 21: 108-115. [online] URL: http://www.ingentaconnect.com/content/ saf/sjaf/1997/00000021/00000003/art00003

Huang Z, Xu Z, Boyd S, Williams D (2005). Chemical composition of decomposing stumps in successive rotation of chinese fir (Cunninghamia lanceolata (Lamb.) Hook.) plantations. Chinese Science Bulletin 50: 2581-2586. - doi: 10.1007/BF 03183654

IPCC (2007). Climate change 2007: the physical science basis. Contribution of Working Group I to the Fourth Assessment Report of the Intergovernmental Panel on Climate Change (Solomon S, Qin D, Manning M, Chen Z, Marquis M, Averyt KB, Tignor M, Miller HL eds). Cambridge University Press, New York, USA, pp. 996.

Irland LC (2000). Ice storms and forest impacts. Science of The Total Environment 262: 231-242. doi: 10.1016/S0048-9697(00)00525-8

Ishii R, Higashi M (1997). Tree coexistence on a slope: an adaptive significance of trunk inclination. Proceedings of the Royal Society of London. Series B 264: 133-140. - doi: 10.1098/rspb. 1997.0020

Klima K, Morgan MG (2015). Ice storm frequencies in a warmer climate. Climatic Change 133: 114. - doi: 10.1007/s10584-015-1460-9

Lemon PC (1961). Forest ecology of ice storms. Bulletin of the Torrey Botanical Club 88: 21-29. doi: $10.2307 / 2482410$

Lindenmayer D, Foster D, Franklin J, Hunter M, Noss R, Schmiegelow F, Perry D (2004). Salvage harvesting policies after natural disturbance. Science 303: 1303. - doi: 10.1126/science. 1093438

Man X, Mi X, Ma K (2011). Effects of an ice storm on community structure of an evergreen broad-leaved forest in Gutianshan National Nature Reserve, Zhejiang Province. Biodiversity Science 19: 197-205. - doi: 10.3724/SP.J.1003.20 11.09220

Meehl GA, Karl T, Easterling DR, Changnon S, Pielke Jr R, Changnon D, Evans J, Groisman PY, Knutson TR, Kunkel KE, Mearns LO, Parmesan C (2000). An introduction to trends in extreme weather and climate events: observations, socioeconomic impacts, terrestrial ecological impacts, and model projections. Bulletin of the American Meteorological Society 81: 413-416. - doi: 10.1175/1520-0477(2000)081<0413:AITTIE>2. 3.CO;2

Millward AA, Kraft CE (2004). Physical influences of landscape on a large-extent ecological disturbance: the northeastern North American ice storm of 1998. Landscape Ecology 19: 99-111. doi: 10.1023/B:LAND.0000018369.41798.2f

Morris JL, Ostrofsky WD (2005). Influence of stand thinning on ice storm injury in Maine hardwood stands. Northern Journal of Applied Forestry 22 (4): 262-267. [online] URL: http:// www.ingentaconnect.com/content/saf/njaf/20 05/00000022/00000004/art00007

Nadrowski K, Pietsch K, Baruffol M, Both S, Gutknecht J, Bruelheide $\mathrm{H}$, Heklau $\mathrm{H}$, Kahl A, Kahl T, Niklaus $P$, Krober $W$, Liu X, Mi X, Michalski SG, Von Oheimb G, Purschke O, Schmid B, Fang T, Welk E, Wirth C (2014). Tree species traits but not diversity mitigate stem breakage in a subtropical forest following a rare and extreme ice storm. PLoS One 9: e96022. - doi: 10.1371/jour nal.pone.0096022

Nielsen C, Van Dyke O, Pedlar J (2003). Effects of past management on ice storm damage in hardwood stands in eastern Ontario. The Forestry Chronicle 79: 70-74. - doi: 10.5558/tfc790 70-1

Päätalo M-L, Peltola H, Kellomäki S (1999). Modelling the risk of snow damage to forests under short-term snow loading. Forest Ecology and Management 116: 51-70. - doi: 10.1016/S0378-112 7(98)00446-0

Platt WJ, Doren RF, Armentano TV (2000). Effects of hurricane Andrew on stands of slash pine (Pinus elliottii var. Densa) in the everglades region of south Florida (USA). Plant Ecology 146: 43-60. - doi: 10.1023/A:1009829319862 Rhoads AG, Hamburg SP, Fahey TJ, Siccama TG, Hane EN, Battles J, Cogbill C, Randall J, Wilson $G$ (2002). Effects of an intense ice storm on the structure of a northern hardwood forest. Canadian Journal of Forest Research 32: 1763-1775. doi: 10.1139/x02-089

Rustadlindsey E, Campbelljohn L (2012). A novel ice storm manipulation experiment in a northern hardwood forest. Canadian Journal of Forest Research 42: 1810-1818. - doi: 10.1139/×2012120

Ryall K, Smith S (2005). Patterns of damage and mortality in red pine plantations following a major ice storm. Canadian Journal of Forest Research 35: 487-493. - doi: 10.1139/x04-180

Schütz J-P, Götz M, Schmid W (2006). Vulnerability of spruce (Picea abies) and beech (Fagus sylvatica) forest stands to storms and consequences for silviculture. European Journal of Forest Research 125 (3): 291-302. - doi: 10.1007/ s10342-006-0111-0

Shao Q, Huang L, Liu J, Kuang W, Li J (2011). Analysis of forest damage caused by the snow and ice chaos along a transect across southern China in spring 2008. Journal of Geographical Sciences 21: 219-234. - doi: 10.1007/s11442-0110840-y

Sterck F, Bongers F (1998). Ontogenetic changes in size, allometry, and mechanical design of tropical rain forest trees. American Journal of Botany 85: 266-272. - doi: 10.2307/2446315 Stokstad E (2006). Salvage logging research continues to generate sparks. Science 311: 761-761. doi: 10.1126/science.311.5762.761 
Stone R (2008). Ecologists report huge storm losses in China's forests. Science 319: 1318-1319. - doi: 10.1126/science.319.5868.1318

Su Z-Y, Liu G, Ou Y-D, Dai Z-H, Li Z-K (2010). Storm damage in a montane evergreen broadleaved forest of Chebaling National Nature Reserve, South China. Chinese Journal of Plant Ecology 34: 213-222. - doi: 10.3773/j.issn.1005-26 4x.2010.02.013

Valinger $E$, Lundqvist $L$ (1992). The influence of thinning and nitrogen fertilization on the frequency of snow and wind induced stand damage in forests. Scottish Forestry 46: 311-320.

Wang X, Huang S, Zhou G, Li J, Qiu Z, Zhao X, Zou $B$ (2009). Effects of the frozen rain and snow disaster on the dominant species of Castanopsis forest in Yangdongshan Shierdushui Provincial Nature Reserve of Guangdong. Scientia Silvae Sinicae 45: 42-47.

Wang B, Wei W, Liu C, You W, Niu X, Man R (2013). Biomass and carbon stock in moso bamboo forests in subtropical china: Characteristics and implications. Journal of Tropical Forest Science 25: 137-148. [online] URL: http://www. jstor.org/stable/43595383

Whitney HE, Johnson WC (1984). Ice storms and forest succession in southwestern Virginia. Bulletin of the Torrey Botanical Club 111: 429-437. doi: $10.2307 / 2995892$

Xi CP (1993). Soil classification system of China. China Agric. Publ. House, Beijing, China, pp. 7585.

Xu J, Li G, Lu Z, Xiang D, Zeng B, Zhang N (2008). Investigation on Eucalypt forest plantations subjected to the freezing catastrophe in southern China. Scientia Silvae Sinicae 44: 103-110. [online] URL: http://en.cnki.com.cn/Article_en/ CJFDTOTAL-LYKE200807023.htm

Yorks TE, Adams KB (2005). Ice storm impact and management implications for jack pine and pitch pine stands in New York, USA. The Forestry Chronicle 81: 502-515. - doi: 10.5558/tfc815 02-4

Zhou B, Cao Y, Wang X, Ge X (2013). Ecological impact assessment on the China's ice storm in 2008. Advanced Materials Research 726: 992996. - doi: 10.4028/www.scientific.net/AMR.72 6-731.992

Zhou B, Fu M, Xie J, Li Z (2005). Ecological functions of bamboo forest: Research and application, Journal of Forestry Research 16: 143-147. doi: 10.1007/BF02857909
Zhou B, Gu L, Ding Y, Shao L, Wu Z, Yang X, Li C, Li Z, Wang X, Cao Y, Zeng B (2011a). The great 2008 Chinese ice storm: its socioeconomic-ecological impact and sustainability lessons learned. Bulletin of the American Meteorological Society 92: 47-60. - doi: 10.1175/2010BAMS2857.1 Zhou B, Li Z, Wang X, Cao Y, An Y, Deng Z, Letu G, Wang G, Gu L (2011b). Impact of the 2008 ice storm on moso bamboo plantations in southeast china. Journal of Geophysical Research: Biogeosciences 116: GooHo6. - doi: 10.1029/20 09JG001234

Zhou B, Yu M, Cao Y, Wang X, Sun H, Ai C, Gu L (2011C). Impact of the 2008 ice storm on China's forests. In: Proceedings of the "International Symposium on Water Resource and Environmental Protection (ISWREP)". Xi'an (China) 2022 May 2011. IEEE Xplore, pp. 2652-2656. - doi: 10.1109/ISWREP.2011.5893423

Zhu J, Li X, Liu Z, Cao W, Gonda Y, Matsuzaki T (2006). Factors affecting the snow and wind induced damage of a montane secondary forest in northeastern china. Silva Fennica 40: 3751. - doi: 10.14214/sf.351 